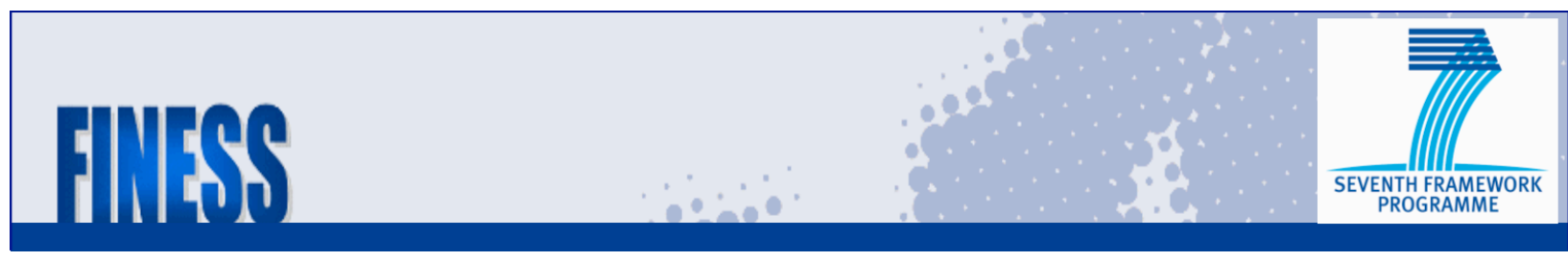

Project funded under the Socio-economic Sciences and Humanities

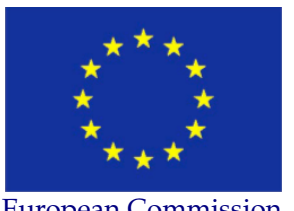

European Commission

Working Paper D.3.1

\title{
Are Private Equity Investors Good or Evil?
}

Oleg Badunenko, Nataliya Barasinska, and Dorothea Schäfer

June 2009 


\title{
Are Private Equity Investors Good or Evil?*
}

\author{
Oleg Badunenko, Nataliya Barasinska, and Dorothea Schäfer ${ }^{\dagger}$
}

The paper investigates the motives of activity (entry and exit) of Private Equity (PE) investors in European companies. Investment of a PE firm is not viewed unambiguously. First, it is claimed that PE investment is made for the sake of seeking shortterm gains by taking control and utilizing the company's resources. Second, a PE firm invests because of prior identification of chances to add value to the company. We attempt to resolve these two conflicting conjectures. We use the Bureau van Dijk's Amadeus database of very large, large and medium-sized European companies. Our major results can be summarized as follows. First, PE firms are less willing to enter the firm if there is already a blocking majority, and they are more likely to leave the firm if control cannot be overtaken. Second, less mature firms are less able to lure a PE firm to invest, thus indicating a safe strategy of PE investors. Third, we do not find empirical evidence that a PE investor comes in to strip a firm of its equity. On the other hand, PE investors are likely to leave the company if it deteriorates in terms of returns and cash. Finally, when comparing the activity of PE and other financial investors, we find essential differences in choosing the field and environment of activity.

Keywords: Private equity financing, leverage, corporate finance

JEL classification: M14, G24, G34

${ }^{*}$ The research leading to these results has received funding from the European Community's Seventh Framework Programme (FP7/2007-2013) under grant agreement number 217266. We thank Christopher F. Baum and Doris Neuberger for helpful comments and suggestions

†German Institute for Economic Research (DIW-Berlin), Mohrenstr., 58, 10117, Berlin, Germany. E-mails are obadunenko@diw.de, nbarasinska@diw.de, and dschaefer@diw.de. 


\section{Contents}

1 Introduction $\quad 1$

2 PE Industry Overview $\quad 3$

3 Drivers of PE Activity $\quad 4$

3.1 Ownership and control in a target firm . . . . . . . . . . . . 5

3.2 Equity or debt capacity of a target firm . . . . . . . . . . . 5

3.3 Maturity of a target firm ................... 6

3.4 Management in a target firm . . . . . . . . . . . . . . . . 6

3.5 Financial system of the target firm's home country . . . . . . . . . . 7

$\begin{array}{lll}4 & \text { Methodology and data } & 7\end{array}$

5 Empirical results $\quad 12$

5.1 Private Equity entry . . . . . . . . . . . . . . . . . . 12

5.2 Private Equity exit . . . . . . . . . . . . . . 16

5.3 Uniqueness of $\mathrm{PE}$ among financial investors . . . . . . . . . . . . . 20

6 Concluding remarks $\quad 23$

$\begin{array}{lr}\text { Literature Cited } & 24\end{array}$

7 Appendix $\quad 28$ 


\section{List of Tables}

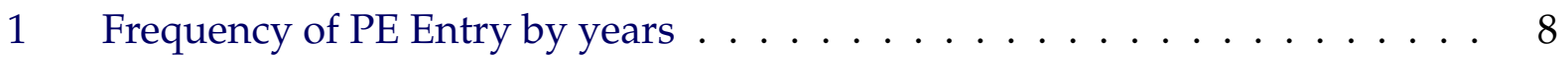

2 Frequency of PE Entry by countries . . . . . . . . . . . . . . . . 10

3 Descriptive Statistics . . . . . . . . . . . . . . . . . . . 12

4 Descriptive Statistics . . . . . . . . . . . . . . . . . . . . 13

5 Marginal effects after logit estimation of PE investment determinants in European companies. The associated $t$-statistics are reported in parentheses. 14

6 Frequency of PE Exits by years . . . . . . . . . . . . . . . . . 17

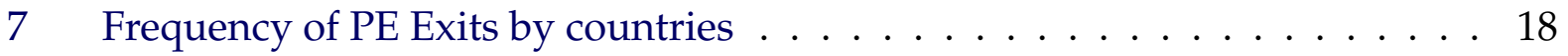

8 Marginal effects after logit estimation of PE investors' exit determinants in European companies. The associated $t$-statistics are reported in parentheses. 19

9 Marginal effects after logit estimation of the entry determinants for non-PE financial investors in European companies. The associated $t$-statistics are reported in parentheses. . . . . . . . . . . . . . . . . . . 21

10 Marginal effects after logit estimation of the exit determinants for non-PE financial investors in European companies. The associated $t$-statistics are reported in parentheses. . . . . . . . . . . . . . . . . . 22

A.1 Marginal effects after logit estimation of PE entry determinants in European companies. The associated $t$-statistics are reported in parentheses. Norway is excluded. . . . . . . . . . . . . . . . . . . 28

A.2 Marginal effects after logit estimation of PE entry determinants in European companies. The associated $t$-statistics are reported in parentheses. The variable 'Lending rate' is included. . . . . . . . . . . . . . . . . . . 29 


\section{List of Figures}

1 Distribution of age of firms that received PE investment . . . . . . . . . . 9

2 Distribution of age of firms that PE investors exited . . . . . . . . . 17 


\section{Introduction}

In many European countries, the importance of private equity (PE thereafter) activity has risen in recent years. At the same time, domestic private equity/buy-out providers have come under increased scrutiny of policy makers. For example, in spring 2008, Germany enacted the Risk Limitation Act in hopes of preventing objectionable economic activities by financial investors without simultaneously impairing efficient financial and corporate transactions. Similar activities have been initiated in other European countries. Despite the fact that the German law concedes a trade-off between the benefits and the costs of PE investment, the fear of the public that PE investors behave as "locusts" once they have entered a firm is still at the center of public debate. PE investors are often blamed for opportunistic behavior, and they are seen as seeking short-term gains by taking control of and utilizing the firm's resources. Furthermore, the fear exists that PE focuses primarily on wealth redistribution that is detrimental for the rest of the firm's stakeholders. The holders of the opposite view, however, see PE as a mechanism that facilitates the development of a firm by overcoming constraints that hinder exploitation of growth opportunities. This view captures the 'welfare-improving' argument. The empirical evidence for these competing views of the phenomenon of private equity is, however, missing. Investigation of the motives of PE engagement in a firm and its impact is lacking (EEAG, 2006).

The need to clarify of the role of PE in corporate financing has become ever more pressing during the financial crisis. The poor functioning of the markets for credit securitization has left deep scars in the private equity industry. In particular, the number and volume of buy-outs in the past year across Europe has declined. At the same time, the acquisition of public equity capital through IPOs and/or capital increases is almost at a standstill. Hardly anything, however, is as important for companies in the current financial crisis as sufficient access to equity capital.

The present paper is the first attempt to study the determinants of private equity activity (investment and exit) in Europe. By analyzing the determinants of PE activity at a micro-level, we intend to address two conflicting conjectures about the motives of PE investors: (i) investing for the sake of pure rent-seeking and (ii) investing because of prior identification of chances to add value to the company.

Because the comprehensive ownership and financial data are largely missing, particularly across countries, previous studies on the determinants of PE investment have focused on mere qualitative analysis (e.g. Thompson and Wright, 1995) or have looked only at particular aspects of the investment decision (e.g. Opler and Titman, 1993). Moreover, the analyses of activity of PE firms have mostly been limited to the US market and to listed firms as target companies. In the latter case, the significant drivers for investment are often indirectly redesigned by means of an event study (e.g. Achleitner et al., 2008). 
In this paper, we examine whether PE investment is motivated by the benefits of relaxing financial constraints and incentive realignment or whether a PE firm is attracted by possibilities of wealth redistribution. We do so by comparing the previous year characteristics of firms that have received a PE shareholder with those that have not. Evidence that PE shareholding is more common in firms with characteristics that indicate severe financial restrictions and/or a high potential for incentive realignment would support the hypothesis that the investment has been motivated by the possibility to create rather than to redistribute wealth. In addition, evidence that firms with a relatively high potential for redistribution are not the dominant targets of PE investors would suggest that concerns about rent-seeking activities are overstated.

PE funds are one particular class among financial investors. Financial institutions, specifically banks, are another prominent class of financial investors. Many researchers have focussed on the role of banks as investors in corporate debt and in equity (see e.g. Cable (1985), Rajan (1992) and John et al. (1994)). Theoretical and empirical research has shown that banks holding equity stakes in the firm often intend to influence corporate control (e.g. Gorton and Schmid, 2000). This research indicates that PE and other financial investors could be driven by similar ideas about their role in their target firms. On the backdrop of this strand of literature, we intend to check in what ways PE investors are indeed unique. Therefore, we compare the entry and exit behavior of PE and other financial investors.

We are interested in a cross-country comparison because different features characterize the financial systems and the capital markets of the countries within the EU. The UK usually sets an example of an extensively market-based financial system, while the German economy has a reputation of being mainly bank-based. Other EU members fall somewhere in between these two extremes. In 2005, the ratio of the stock market capitalization to GDP was 1.26 for the UK and 0.43 for Germany, while for other countries such as France and Hungary (the new EU member state), the ratio was equal to 0.83 and 0.24 , respectively. The picture is less pronounced if we consider the ratio of private credit by deposit money banks to GDP. The indicator ranges from 1.6 for the UK and 1.23 for Germany to 0.96 for France and 0.47 for Hungary. The reason for paying attention to differences in the financial system of a country is twofold. First, the financial system may significantly influence the investment activity of the PE industry (Black and Gilson, 1998). Second, in our econometric setting, the financial environment is most likely to be an important control variable for unobserved cross-country heterogeneity.

We use data from two sources. We build our firm-level dataset from the 2008 (November) edition of the Amadeus database provided by Bureau Van Dijk. The database includes ownership history beginning in 2000. From this base, we retrieve financial ratios, ownership information and other firm-specific variables for companies in all European countries for the years 2000 to 2008 . The country-level data on the nature and evolu- 
tion of the financial system is adopted from the World Bank Financial Structure Database (Beck et al., 2000). ${ }^{1}$

Our major results can be summarized as follows. First, PE firms will invest with lower probability if a blocking majority in the target firm already exists, and it will leave the firm if control cannot be overtaken. Second, risky and financially-constrained target firms have lower chances to receive PE investments. Third, the PE investor does not seem to care much about the management of the company, but when it leaves, labor productivity tends to be higher. Finally, on both entry and exit, PE investors prefer large shareholder funds, yet exit is more likely the lower the firm's cash flow becomes. Additionally, we come to the conclusion that PE investors stand out as a separate type within the class of financial investors. Their activity is driven by other motives than the activities of non-PE financial investors. Overall, our results provide support neither for the "evil" nor for the "angel" hypothesis.

The paper unfolds as follows. In Section 2, we briefly review the literature and sketch the evolution of the PE industry in Europe in last years. We develop behavioral hypotheses based on previous theoretical models and literature in Section 3. Section 4 presents the empirical model and describes the data. The empirical results and their discussion are provided in Section 5, while Section 6 concludes.

\section{PE investments in Europe in recent years}

According to the broad, commonly-used definition in Europe, the activities of PE investors range from complete buy-outs, to minority stakes and expansion capital, to startup and seed investments. Traditionally, the most active PE market in Europe in terms of both fundraising and investing is the United Kingdom, followed by France and Germany (EVCA, 2008). Within a few years, buy-outs have become the most important segment in the PE sector in Europe. The buy-out segment dominates in various countries, including the countries in Central and Eastern Europe such as the Czech Republic, Hungary, and Poland. Since 2003, more than three-quarters of the fundraising of European PE firms were going to the European buy-out segment. The investment of these firms into buyouts increased from more than 60 percent in 2003 to nearly 80 percent in 2007 (EVCA, 2008). In 2007, international financial investors completed 1485 European buy-out deals worth an unprecedented amount of 177 billion Euro (CMBOR, 2008). Both figures fell sharply in 2008. The buy-out market lost about two-thirds of its volume. All deals of 2008 added up to only 69 billion Euro. The number decreased to 1198 . The final quarter of 2008 is particularly responsible for the shrinkage of the market. It showed only 220 buy-outs with a total volume of 10 billion Euro.

\footnotetext{
${ }^{1}$ The financial structure data were accessed at the http: / / siteresources. worldbank. org/ INTRES/Resources / Finstructure_2007.xis.
} 
By buying-out, a PE firm takes control of a company, turns it around, and is willing to sell it or to float its shares after several years. A considerable share of a buy-out price is traditionally debt financed. The debt share in the total acquisition price generally fluctuates between 60 and 80 percent (Axelson et al., 2008). The equity capital for these acquisitions is provided not only by the buy-out funds, but also by the future management of the acquired companies, although to a substantially lesser extent. In the past, the debt capital for European buy-outs generally came from banks and from institutional investors. Upon completion of the acquisition, the different risk-bearing loan tranches are passed on to the participating investors and, in some cases, also to the market. In 2008, due to the financial crisis and the downturn in the market for syndicated and securitized loans, there is a clear tendency towards downsizing of a deal. Specifically, the average deal size shrank to around 58 million Euro in 2008 compared to 118 million Euro during 2007, accompanied by a decrease in leverage ratios (CMBOR, 2008). Anecdotal evidence suggests also that an increasing number of PE firms invest in minority stakes either to use the stake as a platform for acquiring majority stake in the future or to gain a seat on the board for the purpose of increasing and exerting the influence on the target company's business strategy. So called acquisitions by buy-out companies amount to 106 transactions in the UK and Central Europe (CMBOR, 2008). Because the median age of targeted companies in our sample is 16 years, we are set to scrutinize exactly the buy-out segment (whose targets are typically mature firms) as this segment receives ever increased attention.

\section{The factors that influence PE activity}

The reasons for PE investors to acquire stakes, hold them for a certain period, and then sell them to companies, other financial investors or to the public vary. The reasons may include the demand of family owners or individuals for decreasing their cluster risk or the goal to increase earning opportunities by removing a poorly working corporate governance regime. Usually the lifetime of a PE fund ranges from 7 to 10 years. Then, returns have to be distributed to investors mainly pension funds and other institutional investors. Accordingly, by the very definition of its business model, PE is present in a company only for a limited period of time. The reasons for exit are clearly connected to the entry decision. Basically, one would expect that PE fund managers exit if they have reasons to believe that "the job for what they came in is done" or that the chance to achieve the goals has vanished. Therefore, we assume that the motives that drive PE entry affect PE exit as well, although in a modified form. Accordingly, we discuss general behavioral factors that, as the literature identifies, might influence the activity of private equity firms in European countries. 


\subsection{Ownership and control in a target firm}

Berle and Means brought up the issue of a separation of ownership from control already in 1932. They emphasized that dispersion of shareholding creates for each single shareholder an incentive to free ride on the control intensity of company's shareholders. As a result, no control occurs, and the management would pursue all kinds of personal goals to the detriment of the shareholders (Manne, 1965; Williamson, 1967). In line with this argument, active investors buying a share big enough to cover their control costs and combine this deal with a considerable participation of the management in the ownership of the company would reinstate the unity of ownership and control. Dispersed ownership signals the possibility for PE investors to gain high returns (Jensen, 1986). If, however, there is already a powerful shareholder present, this signals to PE investors that the potential for value adding is low. Moreover, the presence of a non-PE financial investor (probably a bank) might imply good performance and low risk but also a lack of opportunities. On the other hand, the inability of the PE firm to acquire control over the firm, and thus manage firm's resources at will, might drive PE investment out.

\subsection{Equity or debt capacity of a target firm}

The ability of PE funds to raise a great deal of debt capital for the acquisition of a target company, in addition to equity capital, has had a strong influence on promoting the negative image of financial investors in many European countries. However, the debt ratio plays a significant part in corporate management. Jensen (1986) describes a high debt ratio as a carrot and stick strategy. On the one hand, it permits a high concentration of the shareholding and a fairly high participation by the management, which guarantees high performance incentives. On the other hand, the high debt and the inherent threat of rapidly losing their position because of the narrow distance to default is like a hard sanction mechanism. In this sense, companies that are highly capitalized indicate slack and a low level of automatically working management control. In addition, highly capitalized companies leave room for savings on corporate taxes. In years with sufficient low-risk premia on loan financing, the leverage effect would guarantee an immediate increase of shareholder return by reorganization of the capital structure (see e.g. The Economist, 2006). The debt can serve as a controlling device and a means of realizing higher tax savings and shareholder returns. However, this powerful device also has controversial implications for PE investors ending their engagement in a firm. The PE investors may leave a company saddled with debt and interest payments after several rounds of equity debt swaps and after the distribution of extra dividends to shareholders. 


\subsection{Maturity of a target firm}

Risky and financially-constrained firms have advantages and disadvantages in attracting PE investors. Small companies, companies that are owned privately and/or by families, are often regarded as being opaque and nontransparent for a potential lender or shareholder. Asymmetric information between companies and investors and moral hazard lead to rationing by lenders (e.g. Bester, 1985) or by the capital market, if the company is listed in an illiquid stock market segment (see Wright et al., 2006). Almeida et al. (2004) argue that constrained firms save a large percentage of cash out of cash flows to be insured against a shortage of liquidity if positive net present values have to be funded. They find that US-firms that are located in the lower quartile of the size distribution indeed accumulate liquidity while larger firms refrain from doing so. Baum et al. (2008) show that European firms in the lower quantiles of the size distribution also stockpile cash out of cash flow. In addition, they find that the magnitude of the stockpiling depends on the structure and development of a country's financial system. Private equity capital may ease the level of financial constraints and improve the capital structure of these firms. The observed close relationship of PE firms, in particular buy-out specialists, with the banking sector may also enable PE investors to activate additional debt capital.

Risky companies face high barriers if they want to raise debt or equity capital from the capital market (The Economist, 2009a). We measure the risk by a company's probability of default (PD), and since banks are not going to grant a credit to a company once it crosses a certain PD threshold, the only way this risky company can obtain capital is from institutional investor(s) such as PE funds. PE investors have gained a reputation of being specialists to turn around a company (e.g. Thompson and Wright, 1995). However, if the evil image of PE investors is true, the engagement into the company would turn the company from being mature - not financially constrained and not risky —into an abysmal state, and exit should be positively affected by these characteristics.

\subsection{Management in a target firm}

PE investors are said to refurbish the market for corporate control and to bring fresh managerial skills to a target company (Wruck, 2008). They do invest when they see a possibility to improve the management and efficiency of a target firm. Since they usually come for a relatively short period of time, they are balancing between making long- and short-term improvements. For example, Williamson (1967) and Jensen (1986) consider excess cash flow (free cash flow) as complementary to high capitalization, and as a further indication of a company's weak corporate governance. Given little debt service, the management enjoys large discretion in spending money on unprofitable projects (see also Opler et al. (1999) and Lehn and Poulsen, 1989). A PE investor targeting such a company may recognize the potential of stopping such practices of wasting resources by restruc- 
turing the company's financing and by initiating a business model that generates more profitable growth.

However, the common public perception of PE investments in mature firms is different. The targeting of "cash cows" is ascribed to the fact that the generated liquidity can be used either to buy back shares on the market or to pay large dividends to shareholders. Both would allow a quick amortization and a high return on the PE investment.

Short-term barometers of a firm's management, such as current labor productivity or return on capital, may indicate possibilities to a PE investor to transfer wealth from employees to shareholders (Betzer, 2006). Fast growing companies may also be a powerful magnet for PE due to their potential to amortize the investment quickly. However, the incumbent shareholders and managers of such a target company may not always be fond of being bought-out because they would lose control over the firm.

\subsection{Financial system of the target firm's home country}

Black and Gilson (1998) suggest that a bank-centered financial system is unable to develop an effective PE industry since its underdeveloped stock markets fail to deliver an efficient exit channel. However, this supply side-driven conclusion may not hold from the point of view of the demand side. Equity capital enables companies to insure themselves against liquidity and income risks. This financing mode is also a "door-opener" for debt capital. With low significance of capital markets in a country's financial system, off-market equity financing may even be more important, since an existing equity capital gap could be closed using such type of financing. PE funds are one of the few available sources for off-market equity capital, and PE capital could in theory at least partly compensate for a lack of public equity capital. Since the financial system of a country is a proxy for the environment in which a PE firm would operate, it should influence PE activity. That is, financial system indicators should be important determinants for both PE entry and PE exit.

Addressing these behavioral hypotheses in a general framework of PE activity, that is PE entry and exit, would indicate whether one of the two conflicting views is favored: PE having welfare-improving characteristics, or PE as a mechanism to redistribute the company's resources and hinder its long-term goals.

\section{Methodology and data}

Shareholder history The data comes from Amadeus Database (Bureau van Dijk.) The Amadeus database contains historical data of shareholders, which runs back to 2000. The database enables us to identify the type of the shareholder, though the classification of the 
Table 1: Frequency of PE Entry by years

\begin{tabular}{rrrc}
\hline Year & $N_{\text {total }}$ & $N_{\text {PE Entry }}$ & PE Entry, $\%$ \\
\hline 2001 & 1,219 & 4 & 0.33 \\
2002 & 2,200 & 37 & 1.68 \\
2003 & 13,659 & 221 & 1.62 \\
2004 & 13,717 & 295 & 2.15 \\
2005 & 22,490 & 428 & 1.90 \\
2006 & 29,601 & 824 & 2.78 \\
2007 & 42,532 & 1,332 & 3.13 \\
2008 & 25,825 & 194 & 0.75 \\
\hline Total & 151,243 & 3,335 & 2.21 \\
\hline
\end{tabular}

PE investment is tricky. We made sure that we really deal with the PE, by inquiring and choosing the appropriate NACE code of the investor and by comparing the names to the established list of the PE firms. ${ }^{2}$ We have generated a dummy variable 'd_P' equal to 1 if at least one PE investor is among the shareholders in a particular year. Variable 'd_P_d' is then the difference of ' $d \_P$ ' in two subsequent years. Accordingly, 'd_P_d' equal to one implies that the PE investor entered in this year. Among a total of 151,243 cases, the data reveals 3,335 PE entries (2.21 percent). The way the dependent variable is constructed precludes a secondary buy-out (Strömberg, 2007). ${ }^{3}$ We only look at the cases when underlying variables suited for the analysis are available. Thus, of approximately 250,000 cases available in the database, the sample reduces to 151,243 observations which is fit for the regression analysis. Table 1 presents the frequency of the variable ' $d \_P \_d$ ' by years. We observe increasing tendency in PE investment up to year 2007 and an abrupt plummet in 2008. Table 1 seems to mirror the aggregate market development in the recent months. The sharp devaluation of mortgage-backed securities and collateralized debt obligations beginning in the midst of 2007 immediately infected other markets for asset-backed securities. Banks are now stockpiling syndicated loans given to PE firms in earlier deals since securitization and distribution to the capital market is not feasible. Leveraged financing of PE deals has dried up as inventories of PE loans for earlier deals have grown in banks' books and risk aversion of credit institutions reached new heights. The deepening financial crisis resulted in a sharp decline of PE investments (e.g. The Economist, 2009b).

$\mathrm{PE}$ in the form of venture capital is said to enter young firms while buy-out investors primarily target older firms. Figure 1 shows the distribution of the age $e^{4}$ of the firms at

\footnotetext{
${ }^{2}$ A subscription was acquired at http://www.privateequityinfo.com.

${ }^{3}$ A secondary buy-out implies that one PE firm acquires the company from another PE firm. Our 'd_P_d' variable indicates that in period $t$, a company has at least one PE investor and that in period $t-1, \mathrm{PE}$ firm(s) was(were) not among company's shareholders.

${ }^{4}$ The age of a company is defined as the difference between the year of the observed PE entry and the year of the company's incorporation.
} 


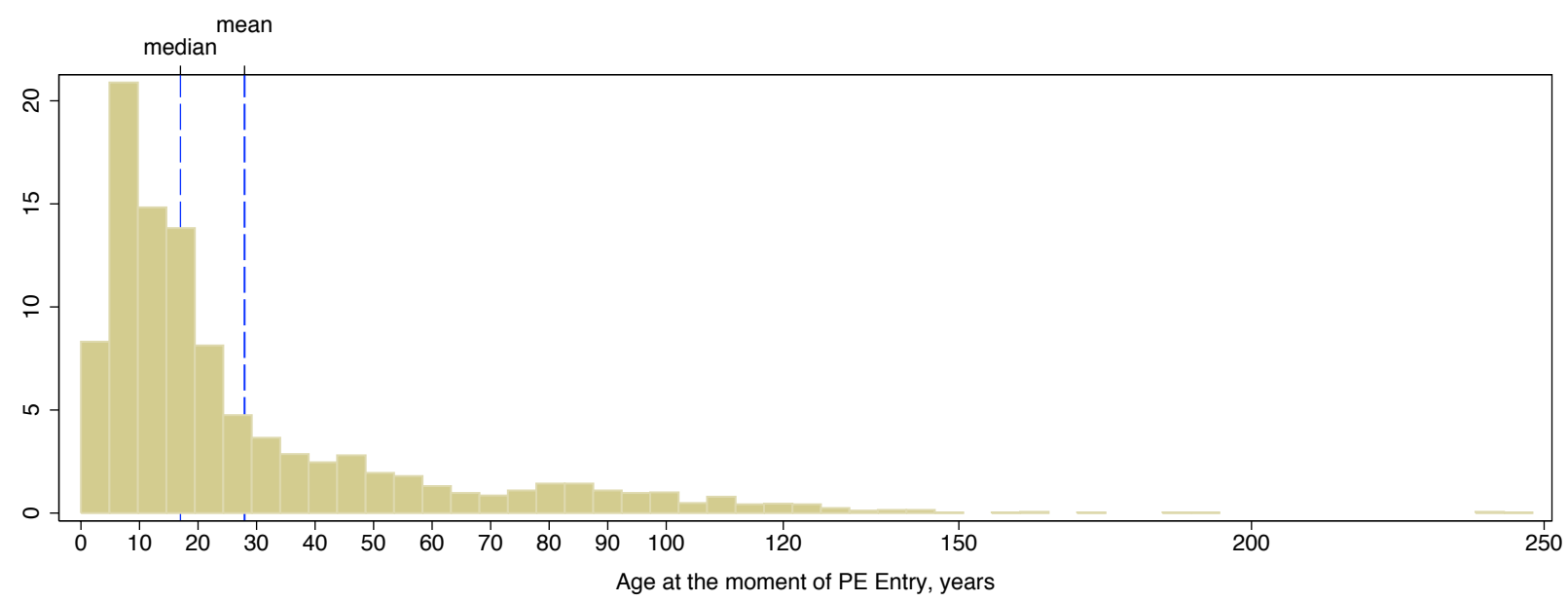

Figure 1: Distribution of age of firms that received PE investment

the moment of PE entrance. The mean and the median are 28 and 16 years respectively. These numbers indicate quite a large share of mature firms.

Table 2 gives frequencies of the PE entries by countries. The United Kingdom, France, and Spain received most of the PE investments, although Ireland and Switzerland have the largest portions of PE entries. Other significant recipients of PE investments are Germany, Italy, Belgium, and Sweden. Norway has the largest number of observations but lags in terms of attracting PE investors: the share is only 0.4 percent.

Specification The aim of the study is to investigate which micro characteristics of the firm in the previous period attract PE investment in the current period. We thus make use of the basic binary choice model, the logistic regression. ${ }^{5}$ As in many empirical applications, we write logit as

$$
\operatorname{Prob}(Y=1 \mid X)=\frac{\exp (\alpha+\beta X)}{1+\exp (\alpha+\beta X)},
$$

where $X$ is a vector of explanatory variables for firm $i$ and $\alpha$ and $\beta^{\prime}$ s are parameters to be estimated. We are primarily interested in regression coefficients. Before presenting our results, let us turn briefly to the description of the vector of explanatory covariates, $X$.

Explanatory variables To test our hypotheses, we generate the following variables. 'Ownership' is equal to one if one of the shareholders has ultimate ownership, ${ }^{6}$ and zero

\footnotetext{
${ }^{5}$ We have chosen the logistic over a probit model. Greene (2003) claims that "...it is difficult to justify the choice of one distribution or another on theoretical grounds."

${ }^{6}$ Ultimate ownership is pre-defined in Amadeus. It is basically the largest shareholder in the firm provided that the shareholder is independent.
} 
Table 2: Frequency of PE Entry by countries

\begin{tabular}{rlrrr}
\hline$\#$ & Country & $N_{\text {total }}$ & $N_{\text {PE Entry }}$ & PE Entry, $\%$ \\
\hline 1 & Ireland & 38 & 14 & 36.84 \\
2 & Switzerland & 812 & 84 & 10.34 \\
3 & Luxembourg & 13 & 1 & 7.69 \\
4 & United Kingdom & 21,025 & 1,065 & 5.07 \\
5 & Austria & 197 & 9 & 4.57 \\
6 & Germany & 5,747 & 254 & 4.42 \\
7 & Netherlands & 2,238 & 85 & 3.80 \\
8 & France & 25,231 & 652 & 2.58 \\
9 & Finland & 2,785 & 52 & 1.87 \\
10 & Spain & 21,890 & 395 & 1.80 \\
11 & Greece & 2,969 & 52 & 1.75 \\
12 & Sweden & 9,081 & 140 & 1.54 \\
13 & Italy & 14,259 & 199 & 1.40 \\
14 & Portugal & 1,523 & 20 & 1.31 \\
15 & Belgium & 11,540 & 143 & 1.24 \\
16 & Poland & 2,406 & 27 & 1.12 \\
17 & Denmark & 1,860 & 20 & 1.08 \\
18 & Czech Republic & 855 & 9 & 1.05 \\
19 & Romania & 2,307 & 24 & 1.04 \\
20 & Hungary & 121 & 1 & 0.83 \\
21 & Estonia & 408 & 3 & 0.74 \\
22 & Slovakia & 211 & 1 & 0.47 \\
23 & Norway & 20,382 & 81 & 0.40 \\
24 & Ukraine & 1,819 & 3 & 0.16 \\
25 & Bulgaria & 1,503 & 1 & 0.07 \\
26 & Latvia & 23 & 0 & 0 \\
\hline & Total & 151,243 & 3,335 & 2.21 \\
\hline & & &
\end{tabular}


otherwise. ' 'Financial investor' is a dummy variable indicating that a non-PE financial investor was among the shareholders. 'Manufacturing' is one if a primary or secondary NACE code implies that the target firm engages in the manufacturing sector of the economy. ${ }^{8}$ The 'Financial Constraint' variable is constructed along the lines of Almeida et al. (2004). More specifically, 'Financial Constraint' is equal to one if the firm's total assets are below the value of the $30^{\text {th }}$ percentile of distribution of the total assets, and zero otherwise. 'Risk' reflects the relative probability of default, that is, the default probability of the firm divided by the probability of default of a peer group. ${ }^{9}$ To calculate the probability of default, Bureau van Dijk uses the MORE rating, ${ }^{10}$ which is calculated using a unique model that references the company's financial data to create an indication of the company's financial risk level. Furthermore, Bureau van Dijk claims that the ratings are comparable across countries-two companies from different countries with the same rating have the same creditworthiness. In order to account for the financial system of a country and the degree of investor protection (LaPorta et al., 2000) we also include a macro variable, 'Market Capitalization', normalized by real GDP, which was accessed from World Bank's online data on the development and structure of a country's financial system. ${ }^{11}$ 'Labor Productivity' measures operating revenues per employee. 'Return on Capital' is return on capital employed. 'Equity' is a continuous variable representing shareholder funds. We normalize 'Equity,' 'Cash Flow' and 'Labor Productivity' by total assets to prevent size effects. 'Cash Flow Growth' is merely the ratio of current to previous value of 'Cash Flow'.

Table 3 presents the descriptive statistics of variables for observations without missing values. It is clear that 'Ownership' is one only in 7.6 percent of cases, while 27 percent of firms are financially constrained. In treating outliers, we have winsorized variables 'Equity', 'Cash Flow', 'Cash Flow Growth', 'Risk' at 0.5 percent and variables 'Labor Productivity' and 'Return on Capital' at 2.5 percent. Although probability of default ranges from 0 to 1, it ranges up to 31 when adjusted for peer probability of default. Such a rel-

\footnotetext{
${ }^{7}$ Since we want to test the hypothesis about dispersed ownership, we also conducted the analysis with the variable 'Dispersed Ownership', which is equal to one if any other type of shareholder has at least a 40 percent stake, and zero otherwise. This variable shows the same effect as the variable 'Ownership' but considerably reduces the sample because 'Direct Ownership, \%' in the Amadeus database has many missing values. That is why we prefer to use the variable 'Ownership' rather than 'Dispersed Ownership.'

${ }^{8}$ Unfortunately, the Amadeus database gives industry affiliation only for the last year, 2008. But we think it is not plausible that a manufacturing firm dramatically changes its operation and quits manufacturing as either its primary or secondary activity.

${ }^{9}$ Defined in Amadeus database.

${ }^{10}$ See http: / / www. modefinance.com for details.

${ }^{11}$ LaPorta et al. (2000) have shown that market capitalization is closely related to the applied legal system and the resulting degree of investor protection. The latest version can be downloaded at http://siteresources.worldbank.org/INTRES/Resources/469232-1107449512766/ FinStructure_2007.xls. The values for the year 2008 are not derived yet, so we assume they are equal to those in 2007. It may seem quite a strong assumption given the events of 2008, but since we conduct a cross-country study, we believe it is reasonable to do so because indices would not change relatively to each other.
} 
Table 3: Descriptive Statistics

\begin{tabular}{lrrrrrrr}
\hline Variable & Mean & Sd & Min & Q1 & Median & Q3 & Max \\
\cline { 2 - 8 } Ownership & 0.076 & 0.26 & 0 & 0 & 0 & 0 & 1 \\
Financial investor & 0.38 & 0.49 & 0 & 0 & 0 & 1 & 1 \\
Manufacturing & 0.31 & 0.46 & 0 & 0 & 0 & 1 & 1 \\
Financial Constraint & 0.27 & 0.44 & 0 & 0 & 0 & 1 & 1 \\
Risk & 2.19 & 4.57 & 0.03 & 0.18 & 0.49 & 1.61 & 31.30 \\
Market Capitalization & 0.84 & 0.37 & 0.026 & 0.56 & 0.84 & 1.02 & 3.03 \\
Labor Productivity & 462 & 728 & 0 & 118 & 219 & 444 & 3831 \\
Cash Flow Growth & 1.10 & 4.32 & -28.0 & 0.58 & 1.01 & 1.44 & 33.40 \\
Return on Capital & 22.8 & 41.3 & -72.7 & 3.77 & 14.3 & 34.2 & 165 \\
Cash Flow & 0.087 & 0.13 & -0.52 & 0.028 & 0.075 & 0.14 & 0.59 \\
Equity & 0.34 & 0.25 & -0.53 & 0.15 & 0.30 & 0.50 & 0.96 \\
\hline
\end{tabular}

ative relationship enables us to control for risk heterogeneity of the group in which the firm is operating. 'Equity' is quite dispersed, but it is distributed symmetrically as mean and median values are almost the same.

In our analysis, we lag (one year) all the explanatory variables, since we are interested in investigating how last year's firm-level characteristics influence receiving investment from a PE firm in the current year.

\section{Empirical results}

\subsection{Private Equity entry}

In this section, we provide empirical evidence on whether our company characteristics, identified as potentially influential, indeed affect the entry and exit decision of PE investors. We consider three models in the regression analysis. The first uses all available observations. It is reasonable to believe that some observations are influential and might drive all the results. Additionally, quite different financial and economic systems might prevent some factors from revealing their true effect. Indeed, a quick look at the Table 2 suggests that the sample of non-EU-15 countries comprises mostly economies unable to attract PE investment. ${ }^{12}$ That is why we also consider a regression with the EU-15 countries. Finally, we analyze the group of EU-27. Table 5 provides the marginal effects of the logit estimation. The descriptive statistics of the variables in three samples employed

\footnotetext{
${ }^{12}$ Please note that neither the EU-15 nor the EU-27 countries are completely represented in the regressions. Representation of a country in the regression depends on data availability.
} 
Table 4: Descriptive Statistics

\begin{tabular}{|c|c|c|c|c|c|c|c|}
\hline \multirow[t]{2}{*}{ Variable } & Mean & Sd & Min & Q1 & Median & Q3 & Max \\
\hline & \multicolumn{7}{|c|}{ Entire Sample } \\
\hline Ownership & 0.076 & 0.26 & 0 & 0 & 0 & 0 & 1 \\
\hline Financial investor & 0.38 & 0.49 & 0 & 0 & 0 & 1 & 1 \\
\hline Manufacturing & 0.31 & 0.46 & 0 & 0 & 0 & 1 & 1 \\
\hline Financial Constraint & 0.27 & 0.44 & 0 & 0 & 0 & 1 & 1 \\
\hline Risk & 2.19 & 4.57 & 0.03 & 0.18 & 0.49 & 1.61 & 31.30 \\
\hline Market Capitalization & 0.84 & 0.37 & 0.026 & 0.56 & 0.84 & 1.02 & 3.03 \\
\hline Labor Productivity & 462 & 728 & 0 & 118 & 219 & 444 & 3831 \\
\hline Cash Flow Growth & 1.10 & 4.32 & -28.0 & 0.58 & 1.01 & 1.44 & 33.40 \\
\hline Return on Capital & 22.8 & 41.3 & -72.7 & 3.77 & 14.3 & 34.2 & 165 \\
\hline Cash Flow & 0.087 & 0.13 & -0.52 & 0.028 & 0.075 & 0.14 & 0.59 \\
\hline \multirow[t]{2}{*}{ Equity } & 0.34 & 0.25 & -0.53 & 0.15 & 0.30 & 0.50 & 0.96 \\
\hline & \multicolumn{7}{|c|}{ EU-15 } \\
\hline Ownership & 0.089 & 0.29 & 0 & 0 & 0 & 0 & 1 \\
\hline Financial investor & 0.35 & 0.48 & 0 & 0 & 0 & 1 & 1 \\
\hline Manufacturing & 0.31 & 0.46 & 0 & 0 & 0 & 1 & 1 \\
\hline Financial Constraint & 0.29 & 0.45 & 0 & 0 & 0 & 1 & 1 \\
\hline Risk & 2.34 & 4.79 & 0.03 & 0.18 & 0.56 & 1.74 & 31.30 \\
\hline Market Capitalization & 0.91 & 0.32 & 0.240 & 0.66 & 0.88 & 1.20 & 2.69 \\
\hline Labor Productivity & 491 & 747 & 0 & 129 & 236 & 475 & 3831 \\
\hline Cash Flow Growth & 1.07 & 4.31 & -28.0 & 0.58 & 1.00 & 1.39 & 33.40 \\
\hline Return on Capital & 19.9 & 37.7 & -72.7 & 3.61 & 13.6 & 31.3 & 165 \\
\hline Cash Flow & 0.080 & 0.12 & -0.52 & 0.026 & 0.070 & 0.13 & 0.59 \\
\hline \multirow[t]{2}{*}{ Equity } & 0.34 & 0.25 & -0.53 & 0.16 & 0.31 & 0.50 & 0.96 \\
\hline & \multicolumn{7}{|c|}{$\mathrm{EU}-27$} \\
\hline Ownership & 0.088 & 0.28 & 0 & 0 & 0 & 0 & 1 \\
\hline Financial investor & 0.34 & 0.47 & 0 & 0 & 0 & 1 & 1 \\
\hline Manufacturing & 0.32 & 0.47 & 0 & 0 & 0 & 1 & 1 \\
\hline Financial Constraint & 0.29 & 0.45 & 0 & 0 & 0 & 1 & 1 \\
\hline Risk & 2.34 & 4.81 & 0.03 & 0.18 & 0.55 & 1.73 & 31.30 \\
\hline Market Capitalization & 0.87 & 0.36 & 0.026 & 0.58 & 0.85 & 1.14 & 2.69 \\
\hline Labor Productivity & 473 & 737 & 0 & 120 & 225 & 459 & 3831 \\
\hline Cash Flow Growth & 1.07 & 4.34 & -28.0 & 0.57 & 1.00 & 1.41 & 33.40 \\
\hline Return on Capital & 19.7 & 37.6 & -72.7 & 3.48 & 13.4 & 31.1 & 165 \\
\hline Cash Flow & 0.081 & 0.12 & -0.52 & 0.026 & 0.070 & 0.13 & 0.59 \\
\hline Equity & 0.34 & 0.25 & -0.53 & 0.16 & 0.32 & 0.51 & 0.96 \\
\hline
\end{tabular}

in the regression are shown in Table 4. It turns out, however, that the differences are not as pronounced as one might think. 
Table 5: Marginal effects after logit estimation of PE investment determinants in European companies. The associated $t$-statistics are reported in parentheses.

\begin{tabular}{|c|c|c|c|}
\hline Variable & ALL & EU-15 & EU-27 \\
\hline Ownership & $\begin{array}{c}-.0102884^{* * * *} \\
(-13.13)\end{array}$ & $\begin{array}{c}-.0139768^{* * *} \\
(-14.84)\end{array}$ & $\begin{array}{c}-.0131894^{* * * *} \\
(-14.82)\end{array}$ \\
\hline Financial investor & $\begin{aligned}-.0135132^{* * * *} & (-21.07)\end{aligned}$ & $\begin{array}{c}-.0146839^{* * * *} \\
(-18.76)\end{array}$ & $\begin{array}{c}-.0138068^{* * * *} \\
(-18.78)\end{array}$ \\
\hline Manufacturing & $\begin{array}{c}.0034802^{* * * *} \\
(-5.03)\end{array}$ & $\begin{array}{c}.0033496^{* * *} \\
(-3.82)\end{array}$ & $\begin{array}{c}.0028519^{* * *} \\
(-3.47)\end{array}$ \\
\hline Financial Constraint & $\begin{array}{c}-.005809^{* * *} \\
(-9.06)\end{array}$ & $\begin{array}{c}-.0077625^{* * * *} \\
(-9.53)\end{array}$ & $\begin{array}{c}-.0072262^{* * * *} \\
(-9.38)\end{array}$ \\
\hline Risk & $\begin{array}{c}-.0008154^{* * * *} \\
(-7.59)\end{array}$ & $\begin{array}{c}-.0010961^{* * * *} \\
(-8.09)\end{array}$ & $\begin{array}{c}-.001055^{* * *} \\
(-8.25)\end{array}$ \\
\hline Market Capitalization & $\begin{array}{c}.0159352^{* * *} \\
(-23.98)\end{array}$ & $\begin{array}{c}.0150157^{* * * *} \\
(-12.8)\end{array}$ & $\begin{array}{c}.0170296^{* * *} \\
(-16.84)\end{array}$ \\
\hline Year & $\begin{array}{c}.0011275^{* * *} \\
(-5.76)\end{array}$ & $\begin{array}{c}.0016561^{* * *} \\
(-6.58)\end{array}$ & $\begin{array}{c}.0016025^{* * *} \\
(-6.74)\end{array}$ \\
\hline Labor Productivity & $\begin{array}{c}2.82 \mathrm{E}-08 \\
(-0.06)\end{array}$ & $\begin{array}{c}-9.82 \mathrm{E}-07 \\
(-1.64)\end{array}$ & $\begin{array}{c}-6.27 \mathrm{E}-07 \\
(-1.12)\end{array}$ \\
\hline Cash Flow Growth & $\begin{array}{c}0.0001133 \\
(-1.6)\end{array}$ & $\begin{array}{c}0.0001676 \\
(-1.87)\end{array}$ & $\begin{array}{c}0.0001466 \\
(-1.74)\end{array}$ \\
\hline Return on Capital & $\begin{aligned}-.0001462^{* * *} & (-10.54)\end{aligned}$ & $\begin{array}{c}-.0001891^{* * * *} \\
(-10.35)\end{array}$ & $\begin{array}{c}-.0001755^{* * *} \\
(-10.23)\end{array}$ \\
\hline Cash Flow & $\begin{array}{c}-0.0063271 \\
(-1.89)\end{array}$ & $\begin{array}{c}-0.0069146 \\
(-1.63)\end{array}$ & $\begin{array}{c}-0.0050691 \\
(-1.26)\end{array}$ \\
\hline Equity & $\begin{array}{c}.0070495^{* * *} \\
(-4.88)\end{array}$ & $\begin{array}{c}.0066156^{* * *} \\
(-3.53)\end{array}$ & $\begin{array}{c}.0052178^{* *} \\
(-2.97)\end{array}$ \\
\hline$N_{\text {total }}$ & 151,243 & 120,396 & 128,230 \\
\hline
\end{tabular}


First, it is clearly seen that if in the previous year a firm had been ultimately owned, the PE investor is less likely to invest in it. Additionally, the presence of a non-PE financial investor seems to repel the PE investor. Therefore, we conclude that a PE firm is reluctant to invest in a firm, in which it cannot take over control.

Second, the positive and significant coefficient of the 'Equity' variable implies that PE investment is more likely when the firm has more equity. It is a long-standing policy debate whether PE investors enter a firm in order to redistribute value. Our analysis seems to provide empirical evidence that PE firms target firms with low debt to profit from an increase in leverage. This may add value by disciplining managers, but it also indicates a potential for reallocating existing equity funds for the benefits of the PE investor. Both entry motives are possible. However, further light on the question of whether the potential for a redistribution of wealth is indeed exploited can be expected from the analysis of the exit decision.

Third, we have seen that the age of the target firm indicates that a PE firm prefers a relatively mature target firm. The regression analysis confirms this conjecture as the coefficient in front of variables 'Financial Constraint' and 'Risk' are negative and significant. The way we constructed the 'Financial Constraint' variable implies that PE is cautious about smaller firms since they could be relatively young and less well-known, which makes them more susceptible to capital market fluctuations. Hence, private equity firms seem to prefer a safe path. On the one hand, this result is bad news for founders of new firms, on the other hand, it indicates that structured finance associated with PE-activity is less risky than market participants currently assume due to the turmoil in the markets for securitized loans (EEAG, 2006).

Fourth, we looked at short- and long-term indicators of management performance. Although it is reasonable to expect that a firm with a high cash flow growth is capital hungry and would attract a PE investor, our analysis does not support this hypothesis. The regression implies that a PE firm makes its decision to invest in a company irrespective of this company's growth of cash flow. Additionally, our regression analysis shows that a PE firm is indifferent with respect to the level of the firm's cash flow. This finding seems to contradict the wide-spread view that PE firms enter to nourish themselves from cash-cows. Nor is the labor productivity of the firm a significant determinant for PE entry. The existing return on capital affects the entry decision in a negative way. This evidence supports the view that PE managers invest if they have identified room for economic and financial improvement.

Finally, PE investors seek to invest in countries whose relative market capitalization is higher. Although this macro variable is used mostly as a control for unobserved heterogeneity of countries, larger capitalization implies better conditions and/or availability of 
financing for a PE firm. Thus, PE seems to be a complement rather than a substitute to public equity, consistent with the supply-side argument of Black and Gilson (1998). ${ }^{13}$

Discarding the slight changes in magnitudes of the coefficients, but taking only significance into account, the results suggest that major conclusions on tested hypotheses found for the entire sample hold for the EU-15 and for all countries in the sample that belong to the EU-27 group. This is expected given the minor differences in descriptive statistics presented in Table 4.

We have also controlled for the year in which PE entry ensued in order to test the influence of a change in the financial environment over time. It seems that time has a positive effect, implying that every year there are more PE entries. We also confirm the view that a PE firm is more likely to invest in a manufacturing firm, although they comprise only one third of our sample. Another concern is Norway's very large number of observations, but very small number of PE entries. We have rerun the regression without Norway (Table A.1 with results appears in the appendix), but this does not change our major conclusions.

\subsection{Private Equity exit}

We have created the variable 'PE Exit' in the same fashion that we constructed the variable 'PE Entry.' More specifically, 'PE Exit' is a binary variable which is equal to one if there is no PE investor among the shareholders in year $t$ and if there was at least one PE investor in year $t-1$. In this section, we would like to investigate the motives of exits of private equity firms within the same context as the entry decision. In other words, we employ the same firm characteristics in order to see what kind of firm investors leave behind when they quit a firm. The frequencies of 'PE Exits' by years and countries are presented in Tables 6 and 7, respectively. Figure 2 shows the age distribution of the firm at the moment of exit of PE.

\footnotetext{
${ }^{13}$ The PE investments can be hypothesized as being motivated by the aim to redistribute wealth to shareholders through increasing leverage in a period of low interest rates. We, therefore, have retrieved the national lending rates from International Financial Statistics-2009 database. Because they are not available for all countries and it is missing for some years, our sample reduces to approximately 128000 , or by $10 \%$. As expected, the effect of the lending rate on PE entry is negative and strongly significant, while other effects do not change (see Table A.2). This speaks in favor of the Axelson et al. (2008) argument that the looser the credit market conditions are, the higher the probability of a deal becomes. We choose, however, not to include this variable for two reasons. First, the sample is cut subject to availability, which means we drop not the whole country from the analysis, but only some years. If we wish to drop a country when the lending rate is not available at least in one year, we will end up following only 11 countries (instead of 26): Bulgaria, Croatia, Czech Republic, Estonia, Hungary, Latvia, Lithuania, Macedonia, Romania, Ukraine, and the United Kingdom. Second, the main virtue of our study is that we analyze determinants of PE activity at the micro-level and include macro variables only to control for an environment. That is why we would like to concentrate on micro-level factors.
} 
Table 6: Frequency of PE Exits by years

\begin{tabular}{rrrc}
\hline Year & $N_{\text {total }}$ & $N_{\text {PE Exit }}$ & PE Exit, \% \\
\hline 2001 & 1,269 & 4 & 0.32 \\
2002 & 2,297 & 13 & 0.57 \\
2003 & 13,911 & 115 & 0.83 \\
2004 & 14,049 & 141 & 1.00 \\
2005 & 22,978 & 256 & 1.11 \\
2006 & 30,125 & 325 & 1.08 \\
2007 & 43,240 & 861 & 1.99 \\
2008 & 27,304 & 584 & 2.14 \\
\hline Total & 155,173 & 2,299 & 1.48 \\
\hline
\end{tabular}

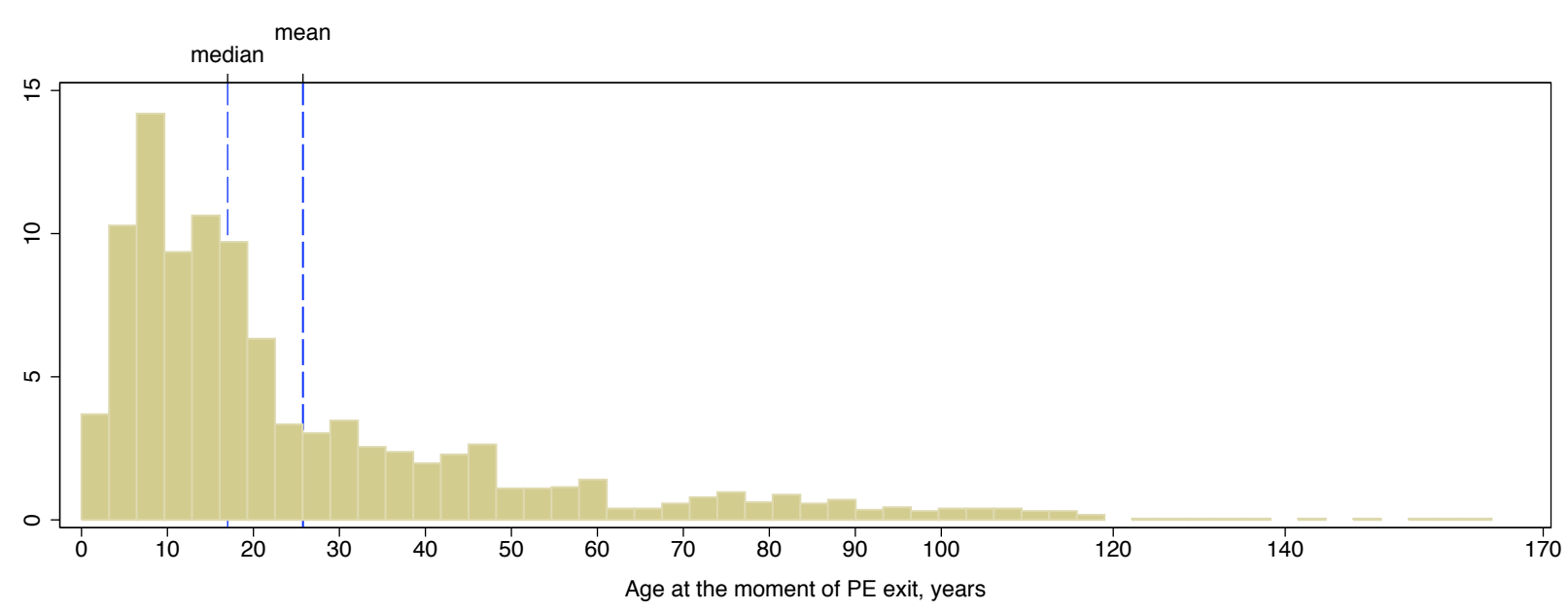

Figure 2: Distribution of age of firms that PE investors exited

Table 6 suggests much lower levels of activity of PE investors in terms of quitting firms during 2001-2008. Figure 2 implies that PE firms have been exiting both young and mature firms with mean and median being almost the same at those for PE entries. Furthermore, PE turnover is again mostly taking place in the United Kingdom, France, and Spain. These three facts suggest that PE firms act consistently and gradually: they exit about the same types of firm in about the same countries as they enter. ${ }^{14}$

\footnotetext{
${ }^{14}$ We do not have enough data to prove PE firms enter and exit in cycles, but we feel it might be the case.
} 
Table 7: Frequency of PE Exits by countries

\begin{tabular}{rlrrr}
\hline$\#$ & Country & $N_{\text {total }}$ & $N_{\text {PE Exit }}$ & PE Exit, $\%$ \\
\hline 1 & Germany & 6,109 & 153 & 2.50 \\
2 & United Kingdom & 22,876 & 534 & 2.33 \\
3 & Netherlands & 2,332 & 48 & 2.06 \\
4 & Czech Republic & 791 & 15 & 1.90 \\
5 & France & 25,962 & 467 & 1.80 \\
6 & Switzerland & 1,024 & 18 & 1.76 \\
7 & Poland & 2,355 & 41 & 1.74 \\
8 & Ireland & 58 & 1 & 1.72 \\
9 & Sweden & 9,139 & 142 & 1.55 \\
10 & Finland & 2,884 & 44 & 1.53 \\
11 & Austria & 198 & 3 & 1.52 \\
12 & Belgium & 11,467 & 163 & 1.42 \\
13 & Spain & 22,299 & 312 & 1.40 \\
14 & Greece & 3,042 & 40 & 1.31 \\
15 & Italy & 14,335 & 186 & 1.30 \\
16 & Estonia & 410 & 5 & 1.22 \\
17 & Denmark & 1,881 & 17 & 0.90 \\
18 & Portugal & 1,550 & 13 & 0.84 \\
19 & Romania & 2,322 & 16 & 0.69 \\
20 & Slovakia & 204 & 1 & 0.49 \\
21 & Norway & 20,462 & 76 & 0.37 \\
22 & Bulgaria & 1,497 & 4 & 0.27 \\
23 & Hungary & 121 & 0 & 0 \\
24 & Latvia & 23 & 0 & 0 \\
25 & Luxembourg & 11 & 0 & 0 \\
26 & Ukraine & 1,821 & 0 & 0 \\
\hline & Total & 155,173 & 2,299 & 1.48 \\
\hline & & &
\end{tabular}

We employ the same set of variables to investigate what drives the final exit of a PE investor. The marginal effects of the logit estimation on private equity exits appear in Table 8.

Several observations from Table 8 are worth mentioning. A PE investor is likely to leave if it was not able to get majority ownership in the firm. That result (effect if significant at any conventional level) implies that getting a strong shareholders' position is a crucial motive for a PE investment.

The regression analysis suggests that PE investors stop caring about whether a firm is financially constrained or risky when they decide about leaving the firm. The 'Risk' 
Table 8: Marginal effects after logit estimation of PE investors' exit determinants in European companies. The associated $t$-statistics are reported in parentheses.

\begin{tabular}{lccc}
\hline Variable & ALL & EU-15 & EU-27 \\
\cline { 2 - 4 } Ownership & $.0078799^{* * * *}$ & $.0061153^{* * *}$ & $.0062746^{* * *}$ \\
Financial investor & $(7.38)$ & $(5.21)$ & $(5.55)$ \\
& $-.0118325^{* * *}$ & $-.0122243^{* * *}$ & $-.011955^{* * *}$ \\
Manufacturing & $(-22.97)$ & $(-19.86)$ & $(-20.51)$ \\
& $.0029846^{* * *}$ & $.003621^{* * *}$ & $.0033^{* * *}$ \\
Financial Constraint & $(5.35)$ & $(5.09)$ & $(4.92)$ \\
& -.000431 & -.0008987 & -.0007965 \\
Risk & $(-0.80)$ & $(-1.33)$ & $(-1.24)$ \\
& -.0001223 & $-.0001722^{*}$ & $-.0001781^{*}$ \\
Market Capitalization & $(-1.80)$ & $(-2.02)$ & $(-2.19)$ \\
& $.0049819^{* * *}$ & $.0046496^{* * *}$ & $.0051684^{* * *}$ \\
Year & $(8.64)$ & $(4.91)$ & $(6.21)$ \\
& $.0026625^{* * *}$ & $.0033938^{* * *}$ & $.0033533^{* * *}$ \\
Labor Productivity & $(15.26)$ & $(15.53)$ & $(16.10)$ \\
& $1.74 \mathrm{e}-06^{* * *}$ & $1.71 \mathrm{e}-06^{* * *}$ & $1.73 \mathrm{e}-06^{* * *}$ \\
Cash Flow Growth & $(5.82)$ & $(4.39)$ & $(4.67)$ \\
& -.0000721 & -.0001152 & -.0001052 \\
Return on Capital & $(-1.28)$ & $(-1.61)$ & $(-1.55)$ \\
& $-.0000243^{*}$ & $-.000027^{*}$ & $-.0000237^{*}$ \\
Cash Flow & $(-2.50)$ & $(-2.14)$ & $(-1.97)$ \\
& $-.0097426^{* * *}$ & $-.0126697^{* * *}$ & $-.0117913^{* * *}$ \\
Equity & $(-3.78)$ & $(-3.88)$ & $(-3.79)$ \\
& $.004901^{* * *}$ & $.0053861^{* * *}$ & $.0047217^{* * *}$ \\
$N_{\text {total }}$ & $(4.26)$ & $(3.63)$ & $(3.37)$ \\
\hline \multirow{2}{*}{,$* * *$ and ${ }^{* * *}$ indicate statistical significance at the $5 \%, 1 \%$, and } & $0.1 \%$ test levels, \\
respectively. & & & \\
& & & 131,866 \\
\cline { 2 - 4 } & 155,173 & 124,143 & \\
& & &
\end{tabular}


variable is, however, weakly significant for the EU-15 and EU-27 group of countries. It implies that exposure of the firm to market fluctuations has a rather weak influence on the decision of PE investors to leave, while it matters a lot in the case of PE entry.

PE investors are more prone to sell off their shares completely if market capitalization is high, which speaks for the argument that PE capital and stock market equity capital are complements. And more exits happen as time passes by, giving some support to the conjecture that PE activity follows certain cycles.

Divestment of PE firms is more likely if operating revenue per employee ('Labor Productivity') increases. Other management indicators have either only weakly significant effects (return on capital), or no significant effect, which suggests that the PE investor's exit is rarely influenced by the state of management of the firm that it is going to leave in the next year.

Finally, the likelihood of a termination of the PE engagement in the firm is lower if the level of cash flow becomes higher. However, PE investors are more prone to leave if the firm is better capitalized. The latter clearly contradicts the hypothesis that PE investors leave their portfolio firms after they have extracted shareholder funds to the detriment of the firm and replaced it with debt. Combining the findings of Tables 5 and 8 , we claim that a PE investor is more likely to enter a better capitalized firm and has a higher probability to leave a better capitalized firm. PE seems not to be attracted by a higher level but it tends to leave the firm when cash flow declines.

\subsection{Uniqueness of PE among financial investors}

PE funds are one particular class of financial investors. Financial institutions, specifically banks, are another prominent class. The role of banks as investors in corporate debt and in equity has achieved a lot of attention in the past. It has been argued that banks that invest in equity stakes often intend to control and influence the target company's management. This research implies that the whole class of financial investors could share common motives that drive both corporate investment and divestment activities. In this section, we empirically compare PE and other financial investors in order to check whether the factors that influence the decision to invest pertain to PE investor, or whether they can be generalized to other financial investors as well.

Tables 9 and 10 present the marginal effects after logit estimation of the determinants of entry and exit decisions of non-PE financial investors. There are four essential differences between drivers of PE and non-PE financial investors' activity that are worth mentioning.

First, a non-PE financial investor is likelier to invest as well as exit the company in a given year if at least one PE investor was present in the previous year. Regarding investment, the banks and other financial investors might take the presence of PE as a positive 
Table 9: Marginal effects after logit estimation of the entry determinants for non-PE financial investors in European companies. The associated $t$-statistics are reported in parentheses.

\begin{tabular}{lccc}
\hline Variable & ALL & EU-15 & EU-27 \\
\cline { 2 - 4 } Ownership & $-.0115684^{* * *}$ & $-.00943^{* * *}$ & $-.0084598^{* * *}$ \\
& $(-5.47)$ & $(-4.41)$ & $(-4.00)$ \\
PE investor & $.0362341^{* * *}$ & $.0386121^{* * *}$ & $.0361408^{* * *}$ \\
& $(12.88)$ & $(13.47)$ & $(13.04)$ \\
Manufacturing & .0011547 & .0013848 & .001865 \\
& $(0.85)$ & $(0.96)$ & $(1.33)$ \\
Financial Constraint & $-.0119375^{* * *}$ & $-.0102586^{* * *}$ & $-.0090236^{* * *}$ \\
& $(-8.90)$ & $(-7.28)$ & $(-6.56)$ \\
Risk & $-.0022486^{* * *}$ & $-.0022204^{* * *}$ & $-.0021853^{* * *}$ \\
& $(-10.73)$ & $(-10.32)$ & $(-10.56)$ \\
Market Capitalization & $-.0062282^{* * *}$ & $-.0072217^{* * *}$ & $-.0056995^{* *}$ \\
& $(-3.69)$ & $(-3.49)$ & $(-3.12)$ \\
Year & $.0037257^{* * *}$ & $.0045157^{* * *}$ & $.0042675^{* * *}$ \\
& $(9.05)$ & $(10.25)$ & $(9.97)$ \\
Labor Productivity & $-3.92 \mathrm{e}-07$ & $1.32 \mathrm{e}-06$ & $1.16 \mathrm{e}-06$ \\
& $(-0.45)$ & $(1.50)$ & $(1.33)$ \\
Cash Flow Growth & .0001756 & .0000834 & .0000728 \\
& $(1.23)$ & $(0.55)$ & $(0.50)$ \\
Return on Capital & $-.000223^{* * *}$ & $-.000325^{* * * *}$ & $-.0003144^{* * *}$ \\
& $(-9.13)$ & $(-11.43)$ & $(-11.33)$ \\
Cash Flow & .0035899 & .00144 & -.000198 \\
& $(0.52)$ & $(0.20)$ & $(-0.03)$ \\
Equity & $-.0082258^{* *}$ & -.0034602 & -.0040337 \\
& $(-2.72)$ & $(-1.07)$ & $(-1.30)$ \\
\cline { 2 - 4 }$N_{\text {total }}$ & 133,495 & 108,793 & 115,696 \\
\hline \multirow{2}{*}{,$* *$ and ${ }^{* * *}$ indicate statistical significance at the 5\%, $1 \%$, and } & $0.1 \%$ test levels, \\
respectively; & & & \\
& & &
\end{tabular}


Table 10: Marginal effects after logit estimation of the exit determinants for non-PE financial investors in European companies. The associated $t$-statistics are reported in parentheses.

\begin{tabular}{lccc}
\hline Variable & ALL & EU-15 & EU-27 \\
\cline { 2 - 4 } Ownership & $.0179149^{* * * *}$ & $.0094569^{* * *}$ & $.0102264^{* * *}$ \\
PE investor & $(8.58)$ & $(4.84)$ & $(5.20)$ \\
& $.0105665^{* * *}$ & $.0087809^{* * *}$ & $.00713^{* * *}$ \\
Manufacturing & $(5.81)$ & $(4.62)$ & $(3.83)$ \\
& .0012935 & -.0006294 & .0003782 \\
Financial Constraint & $(1.28)$ & $(-0.55)$ & $(0.34)$ \\
& .0008688 & -.0014861 & -.0005935 \\
Risk & $(0.83)$ & $(-1.28)$ & $(-0.52)$ \\
& $-.000372^{* *}$ & $-.000387^{* *}$ & $-.0004616^{* *}$ \\
Market Capitalization & $(-2.90)$ & $(-2.71)$ & $(-3.27)$ \\
& $-.0125643^{* * *}$ & $-.0232335^{* * *}$ & $-.0233492^{* * *}$ \\
Year & $(-9.68)$ & $(-13.93)$ & $(-15.70)$ \\
& $.0047257^{* * *}$ & $.0080327^{* * *}$ & $.0075785^{* * *}$ \\
Labor Productivity & $(14.87)$ & $(22.00)$ & $(21.14)$ \\
& $1.64 \mathrm{e}-06^{* *}$ & $8.40 \mathrm{e}-07$ & $6.99 \mathrm{e}-07$ \\
Cash Flow Growth & $(2.62)$ & $(1.18)$ & $(0.97)$ \\
& .0000165 & .0000159 & $9.88 \mathrm{e}-06$ \\
Return on Capital & $(0.15)$ & $(0.13)$ & $(0.08)$ \\
& $-.0001202^{* * *}$ & $-.0000952^{* * *}$ & $-.0000898^{* * *}$ \\
Cash Flow & $(-6.61)$ & $(-4.46)$ & $(-4.24)$ \\
& $-.0175553^{* * *}$ & $-.0122281^{*}$ & $-.0169216^{* *}$ \\
Equity & $(-3.49)$ & $(-2.12)$ & $(-2.99)$ \\
& $.00672^{* *}$ & .0031803 & .0036769 \\
$N_{\text {total }}$ & $(3.05)$ & $(1.23)$ & $(1.47)$ \\
\hline \multirow{2}{*}{${ }^{* * * *}$, and ${ }^{* * *}$ indicate statistical significance at the $5 \%, 1 \%$, and } & $0.1 \%$ test levels, \\
respectively; & & & \\
& & &
\end{tabular}


signal for the potential of the firm (Janney and Folta, 2003). However, the fact that a nonPE financial investor is more willing to leave if a PE investor is present might indicate that sharing corporate control among strategically-oriented financial investors is a rather difficult task.

Second, in contrast to PE funds, other financial investors have no particular preference for the manufacturing sector. Third, non-PE financial investors are active with larger probability in countries that have low levels of market capitalization. This observation is in line with the notion that in low market-capitalized financial systems, so-called bank based systems, banks invest in firm debt but also to a fairly large extent in firms' equity. Fourth, if we control for the countries of the European Union, or restrict the analysis to the economies in our sample that belong to the EU-15 or EU-27 groups, non-PE investors' decisions to either invest in the company or to leave the company are independent of how large the debt capacity of this company is. When we, however, take all countries into consideration, non-PE financial investors seem to be more likely to enter if the debt capacity is low and more likely to exit if the debt capacity is high. Such findings would be in line with the notion that shareholding of banks is often initiated by a bank's position as a relationship lender (Elsas and Krahnen, 2003).

\section{Concluding remarks}

In recent years, policy makers have become increasingly concerned with reconciling two contradicting views on the role of PE for the economy in general and for companies in which they invest in particular. First, it is conjectured that engagement of a PE investor may and does provide the financing needed for development of the company, and thus such engagement constitutes positive effects. Second, some share a view that a PE investor enters a company that has good perspectives in order to squeeze that company's cash and capital resources, therefore implying negative effects. However, to the best of our knowledge, testing these conceptually opposite hypotheses with good quality data is broadly missing. This paper provides empirical evidence for a better understanding of what makes a PE firm invest using comprehensive micro-data for 26 European countries.

Our results suggest that when investing, PE fund managers seem to care and are less willing to enter a firm if another party already holds ultimate ownership or is the majority shareholder. Consistent with this observation on the entry decision, they want to leave the firm if majority shareholding by another investor signals that they cannot take over control.

Additionally we find that a financially-constrained and risky company is less successful in attracting investment from a PE firm. However, these two factors do not influence the decision of PE fund managers to leave. Furthermore, when investing, the PE firm does not show more interest in firms with better management, but it is more likely to exit 
when the firm has higher labor productivity. Most remarkably, while PE wants to exit the firm when cash flow decreases, it tends to invest in and leave the firm that has larger shareholder funds.

The proposed analysis provides support neither for the "evil" nor for the "angel" hypothesis. We could not find strong signs that private equity investments are mainly motivated by the aim to add value. At the same time, we were unable to provide support for the view of PE investors as asset strippers. We find, however, that PE investors are quite normal investors that intend to avoid an observably high risk and shy away from vulnerable and possibly opaque firms. Furthermore, there is clear evidence that PE capital and equity capital from stock markets are not substitutes but complements. Finally, PE investors opt to engage in sound companies and prefer to deal with mostly mature firms.

There are similarities but also significant differences between PE investors and nonPE financial investors. In contrast to their counterparts, PE investors play a special role in providing equity capital to the capital-intensive manufacturing sector. We also found that PE serves as a complement to the public capital provided by stock exchanges whereas non-PE financial investors rather seem to substitute such public capital. However, the often-observed joint presence of PE and other financial investors in the company also hints at a largely neglected phenomenon in the existing research on private equity: the "division of labor" between different types of financial investors (Neuberger, 2009).

Finally, we would like to emphasize, however, that one has to be cautious when evaluating the results. First, the purpose of our analysis was a cross-country comparison and, therefore, our conclusions apply to an 'average' European company. Nevertheless, including the macro control variable 'Market Capitalization' into our regressions has shown that countries are statistically significantly heterogeneous and a separate analysis for each country may be beneficial to complete the picture. This is, however, possible only for a handful of countries due to data availability. Second, although we believe that our conclusions are robust, we would like to acknowledge that some countries are poorly represented and that broad conclusions might not necessarily hold for such countries or regions.

\section{References}

Achleitner, Ann-Kristin, Christian Andres, André Betzer, and Charlie Weir (2008) 'Economic consequences of private equity investments on the german stock market.' Technical Report, Aberdeen Business School, The Robert Gordon University, Schotland

Almeida, Heitor, Murillo Campello, and Michael S. Weisbach (2004) 'The cash flow sensitivity of cash.' The Journal of Finance LIX(4), 1777-1804 
Axelson, Ulf, Tim Jenkinson, Per Strömberg, and Michael S. Weisbach (2008) 'Leverage and pricing in buyouts: An empirical analysis.' OFRC Working Papers Series 2008fe20, Oxford Financial Research Centre

Baum, Christopher F., Dorothea Schäfer, and Oleksandr Talavera (2008) 'The impact of financial structure on firms' financial constraints: A cross-country analysis.' Boston College Working Papers in Economics 690, Boston College Department of Economics, October

Beck, Thorsten, Asli Demirgüç-Kunt, and Ross Levine (2000) 'A new database on financial development and structure.' World Bank Economic Review 14, 597-605

Berle, Adolf A., and Gardener Means (1967) The Modern Corporation and Private Property, 2nd ed. (Harcourt, Brace and World). ISBN 0887388876

Bester, Helmut (1985) 'Screening vs. rationing in credit markets with imperfect information.' American Economic Review 75(4), 850-55

Betzer, A. (2006) 'Why private equity investors buy dear or cheap in european leveraged buyout transactions?' Kredit und Kapital 3(39), 397-417

Black, Bernard S., and Ronald J. Gilson (1998) ‘Venture capital and the structure of capital markets: Banks versus stock markets.' Journal of Financial Economics 47, 243-277

Cable, John R. (1985) 'Capital market information and industrial performance: The role of West German banks.' Economic Journal 95(377), 118-132

CMBOR (2008) 'European management buy-outs January-June 2008.' Centre for Management Buy-out Research, Nottingham University Business School Jubilee Campus, Wollaton Road University of Nottingham

EEAG (2006) 'Private equity, the EEAG report on the European economy 2009.' European Economic Advisory Group, Munich pp. 123-140

Elsas, Ralf, and Jan Pieter Krahnen (2003) 'Universal banks and relationships with firms.' CFS Working Paper Series 2003/20, Center for Financial Studies, January

EVCA (2008) 'EVCA yearbook 2008.' European Private Equity and Venture Capital Association (EVCA)

Gorton, Gary, and Frank A. Schmid (2000) 'Universal banking and the performance of German firms.' Journal of Financial Economics 58(1-2), 29-80

Greene, William H. (2003) Econometric Analysis, 5th ed. (Prentice Hall) 
Janney, Jay J., and Timothy B. Folta (2003) 'Signaling through private equity placements and its impact on the valuation of biotechnology firms.' Journal of Business Venturing 18(3), 361-380

Jensen, Michael C (1986) 'Agency costs of free cash flow, corporate finance, and takeovers.' American Economic Review 76(2), 323-329

John, Kose, Therese A. John, and Antony Saunders (1994) 'Universal banking and firm risk taking.' Journal of Banking \& Finance 18, 307-323

LaPorta, Rafael, Florencio Lopez de Silanes, Andrei Shleifer, and Robert Vishny (2000) 'Investor protection and corporate governance.' Journal of Financial Economics 55(1), 327

Lehn, Kenneth, and Annette Poulsen (1989) 'Free cash flow and stockholder gains in going private transactions.' Journal of Finance 44(3), 771-787

Manne, Henry G. (1965) 'Mergers and the market for corporate control.' Journal of Political Economy 73, 351

Neuberger, Doris (2009) 'Finanzierungs- und governance-strukturen im wandel : Arbeitsteilung zwischen banken und private equity fonds.' Vierteljahrshefte zur Wirtschaftsforschung / Quarterly Journal of Economic Research 78(1), 143-155

Opler, Tim, and Sheridan Titman (1993) 'The determinants of leveraged buyout activity: Free cash flow vs. financial distress costs.' The Journal of Finance 48(5), 1985-1999.

Opler, Tim, Lee Pinkowitz, Rene Stulz, and Rohan Williamson (1999) 'The determinants and implications of corporate cash holdings.' Journal of Financial Economics 52(1), 3-46

Rajan, Raghuram G. (1992) 'Insiders and outsiders: The choice between informed and arm's-length debt.' Journal of Finance 47, 1367-1400

Strömberg, Per (2007) 'The new demography of private equity.' Technical Report, Swedish Institute for Financial Research Stockholm School of Economics

The Economist (2006) 'Barbarians at the gates of Europe.' Print edition, Feb, 16th $378(8465), 61-62$

_ (2009a) 'A gallant effort.' Print edition, Jan 15th 390(8614), 32

_ (2009b) ‘Roll up, roll up.' Print edition, Jan 8th 390(8613), 62-63

Thompson, Stephe, and Mike Wright (1995) 'Corporate governance: The role of restructuring transactions.' The Economic Journal 105(430), 690-703 
Williamson, Oliver E. (1967) 'Hierarchical control and optimum firm size.' Journal of Political Economy 75, 123

Wright, Mike, Tomas Simons, and Luc Renneboog (2006) ‘Why do Public Firms go Private in the UK?' SSRN eLibrary

Wruck, Karen H. (2008) 'Private equity, corporate governance, and the reinvention of the market for corporate control.' Journal of Applied Corporate Finance 20(3), 8-21 


\section{Appendix}

Table A.1: Marginal effects after logit estimation of PE entry determinants in European companies. The associated $t$-statistics are reported in parentheses. Norway is excluded.

\begin{tabular}{lc}
\hline Variable & ALL \\
\cline { 2 - 2 } Ownership & $-.0130595^{* * *}$ \\
Financial investor & $(-14.66)$ \\
& $-.013061^{* * *}$ \\
Manufacturing & $(-17.91)$ \\
& $\left(-004021^{* * *}\right.$ \\
Financial Constraint & $-.0079295^{* * *}$ \\
& $(-10.46)$ \\
Risk & $-.0010799^{* * *}$ \\
& $(-8.37)$ \\
Market Capitalization & $.0165938^{* * *}$ \\
& $(-20.93)$ \\
Year & $.0016521^{* * *}$ \\
& $(-7.04)$ \\
Labor Productivity & $-6.40 \mathrm{E}-07$ \\
& $(-1.15)$ \\
Cash Flow Growth & 0.0001452 \\
& $(-1.73)$ \\
Return on Capital & $-.0001778^{* * *}$ \\
& $(-10.08)$ \\
Cash Flow & -0.0039256 \\
& $(-0.99)$ \\
Equity & $.0044613^{* *}$ \\
& $(-2.58)$ \\
$N_{\text {total }}$ & 130,861 \\
\hline
\end{tabular}

$*, * *$, and ${ }^{* * *}$ indicate statistical significance at the $5 \%, 1 \%$, and $0.1 \%$ test levels, respectively. 
Table A.2: Marginal effects after logit estimation of PE entry determinants in European companies. The associated $t$-statistics are reported in parentheses. The variable 'Lending rate' is included.

\begin{tabular}{|c|c|}
\hline Variable & ALL \\
\hline Ownership & $\begin{array}{c}-.0114241^{* * *} \\
(-13.22)\end{array}$ \\
\hline Financial investor & $\begin{array}{c}-.0131283^{* * *} \\
(-18.64)\end{array}$ \\
\hline Manufacturing & $\begin{array}{c}.0041372^{* * *} \\
(5.34)\end{array}$ \\
\hline Financial Constraint & $\begin{array}{c}-.0056274^{* * *} \\
(-7.72)\end{array}$ \\
\hline Risk & $\begin{array}{c}-.0008383^{* * *} \\
(-6.98)\end{array}$ \\
\hline Market Capitalization & $\begin{array}{c}.0136878^{* * *} \\
(15.07)\end{array}$ \\
\hline Lending rate & $\begin{array}{c}-.001472^{* * *} \\
(-7.61)\end{array}$ \\
\hline Year & $\begin{array}{c}.0019187^{* * *} \\
(7.82)\end{array}$ \\
\hline Labor Productivity & $\begin{array}{c}-6.29 \mathrm{e}-07 \\
(-1.22)\end{array}$ \\
\hline Cash Flow Growth & $\begin{array}{c}.0001367 \\
(1.75)\end{array}$ \\
\hline Return on Capital & $\begin{array}{c}-.0001434^{* * *} \\
(-9.01)\end{array}$ \\
\hline Cash Flow & $\begin{array}{c}-.0073119 \\
(-1.96)\end{array}$ \\
\hline Equity & $\begin{array}{c}.0063029^{* * *} \\
(3.92)\end{array}$ \\
\hline$N_{\text {total }}$ & 128,681 \\
\hline
\end{tabular}

$*, * *$, and ${ }^{* * *}$ indicate statistical significance at the $5 \%, 1 \%$, and $0.1 \%$ test levels, respectively. 